Original Research Paper

\title{
Effects of Anthropogenic Activity on Stream Water Quality in Langsa, Aceh
}

\author{
Helmy Akbar ${ }^{*}$, Iwan Suyatna ${ }^{1}$, Jailani ${ }^{1}$, Singgih Afifa Putra ${ }^{2}$ and Fauziah Azmi ${ }^{3}$ \\ ${ }^{1}$ Department Living Aquatic Resources Management, Fakultas Perikanan dan Ilmu Kelautan, \\ Mulawarman University, Indonesia \\ ${ }^{2}$ Departemen Kelautan dan Perikanan, Lembaga Pengembangan dan Pemberdayaan Pendidik dan \\ Tenaga Kependidikan Bidang Kelautan Perikanan Teknologi Informasi dan Komunikasi (LPPPTK \\ KPTK), Sulawesi Selatan, Indonesia \\ ${ }^{3}$ Department Aquaculture, Faculty of Agriculture, Samudra University, Langsa, Aceh. Jl. Meurandeh \\ Daya, Kecamatan Langsa Lama, Kota Langsa, Indonesia
}

\author{
Article history \\ Received: August 10 $10^{\text {st }}, 2018$ \\ Revised: November $6^{\text {st }}, 2018$ \\ Accepted: November $11^{\text {st }}$, \\ 2018 \\ Published: November $21^{\text {st }}$, \\ 2018 \\ *Corresponding Author: \\ Akbar, Department Living \\ Aquatic Resources \\ Management, Faculty of \\ Fisheries and Marine Science, \\ Mulawarman University, \\ Indonesia; \\ Email: \\ helmy.akbar85@gmail.com
}

\begin{abstract}
Increased human activity towards the water bodies will change the condition of water quality. This study aimed to analyze the impact of type $\mathrm{C}$ surface mining materials, land clearing and land grabbing at the river to water environment parameters (flow velocity, depth, turbidity, temperature, water transparency, Total Suspended Solid (TSS), pH, Dissolved Oxygen (DO) and Biological Oxygen Demand (BOD)) and the change of makrozoobenthos community structure using EPT (Ephemeroptera, Plecoptera and Trichoptera) Index. The method was a survey by collecting the water quality samples taken from 9 stations/ set with two repetitions, Samples value were compared with the supporting literature, expert opinions and Indonesian Government Regulation from Ministry of Living Environment (PP No. 82 tahun 2001). Case study in Langsa, Aceh, It was found that an increase in Some physical parameter (TSS) that exceeds the value determined in indonesian government regulation. The high value of TSS in Station 2 and Station 3 indicates that the sediment loading to the water body is high, especially in Station 3, where the TSS concentrations far exceed the standard. Activity of type $\mathrm{C}$ surface mining materials tends to affect the brightness, turbidity, depth and TSS. Water conditions with low $\mathrm{pH}$ were also found in this study. In location studied no EPT larvae were found.
\end{abstract}

Keyword: Aceh, Langsa, Water Quality, Stream, Total Suspended Solid, Anthropogenic Activity

\section{Introduction}

The growth of the agricultural sector, especially plantations, is one of the factors supporting the growth of the Indonesian economy in recent decades. Palm oil is one of the main commodities where Indonesia has been the largest palm oil exporter in the world since 2007. The area of palm oil plantation in Indonesia reaches almost 8.7 ha owned by community, corporations and government (Comte 2012). This growth has the support of the government because it plays an important role in improving the Indonesian economy and poverty alleviation through the provision of employment (Susila 2004). Even the Indonesian government is targeting CPO production of 40 million tons by 2020 (Comte et al 2015).

The conversion of forest to agricultural land, especially for palm oil plantation, also has an impact on the environment such as the changing of soil chemical properties (Irfan and Huda 2012). In addition to the effects on terrestrial ecosystems (forests), oil palm plantations also have impacts on water areas such as rivers and steams. Among the effects are increased sediment load, turbidity, Total Suspended Solid (TSS), Biochemical Oxygen Demand (BOD) which will also lead to decreased oxygen levels and biodiversity loss. (Yusop, Chan, and Katimon 2007). 
Currently, the rejuvenation of palm oil plantation is happening in some areas in Langsa city. Rejuvenation activities include old palm cutting and clearing of land from palm root that has been cut. This activity is suspected to cause an abundance of sediment and organic matter to water bodies closest to cleared land, one of which is Alur Buaya river, located in Alur Buaya Hamlet, Langsa City.

Activities carried out in oil palm plantations may cause some environmental problems such as the entry of sediments and disposal of organic material from plantations to nearby water bodies that cause decreased water quality in rivers or creeks (Yaap et al. 2010). To determine whether an aquatic ecosystem is of good or bad quality, there are several physical / chemical parameters that can be used as benchmarks, including total suspended solids (TSS), Biochemical Oxygen Demand (BOD), and Dissolved Oxygen (DO) (Juahir et al., 2011).

Increased concentrations of suspended solids and BOD may cause problems in water bodies such as decreased dissolved oxygen (DO) (Whitehead et al. 2009), leading to the death of organisms such as fish and changes in community structure and ecosystem dynamics, where organisms are intolerant of decline Water quality will be replaced by more tolerant organisms (Dodds 2006)

Measurement of chemical physics parameters has long been used as a reference quality of aquatic ecosystems. The measurement results provide information about the good or bad of a waters area at the time of sampling. However, physics / chemical parameters can not describe the changing conditions occurring in a waters area over time, therefore, biomonitoring is used as an alternative measurement that provides a more comprehensive picture than the physical / chemical parameter measurement only (Zimmerman 1993).

A large number of organisms have been used as indicators of watershed environmental quality (Burger et al., 2013; Zuloaga et al. 2009; Wu 1984), but practitioners and academics have consistently selected macroinvertebrates as bioindicators (Hepp and Santos 2008). Among these macroinvertebrates, water insects from the ephemeroptera, Plecoptera and Trichoptera (EPT) unmarried (larva) order, are the most widely used taxa in biomonitoring in the lotic ecosystem. (Hamid et al., 2012)
The study of the ecological conditions and ecosystems of stream waters in the Aceh region has not been much done, especially in terms of assessing the health of rivers or streams. Study by Ichwana et. al. (2013) on several sub watershed rivers in Krueng Peusangan, Aceh, it was more determined to groundwater recharge from stream flow. Studies conducted by M. Irham et. al. (2018) displays spatial distribution of suspended sediment along Krueng Cut River, Banda Aceh. However, it has not explained the biophysical and chemical aspects of the waters and the description of the ecological conditions. Previously, Mulyani et. al. (2012) has conducted research on aspects of river water quality spatial analysis based on physical parameters throughout Krueng Daroy River in Banda Aceh. The data measured includes temperature, turbidity, color, $\mathrm{pH}$, odor, TDS and electrical conductivity. So far the research that combines biophysical and chemical aspects of waters has not been published. Therefore this study was conducted to assess the quality of stream waters that have been subjected to ecological pressure due to human activities (anthropogenic factors)

\section{Method and Data Analysis}

Standard for physico-chemical characteristic determined in PP Number 82 Tahun (year) of 2001 (Indonesian government standard) on the Management of Water Quality and Control of Water Pollution- Class II (for agriculture, fishery and livestock), for measure ecological condition of stream. At the research using The EPT Richness Index (including $\mathrm{E}=$ Ephemeroptera, $\mathrm{P}=$ Plecoptera, $\mathrm{T}=$ Trichoptera) to estimate water quality by looking at the relative abundance of the three main stream water insect that have low tolerance to water pollution. EPT can be expressed as a percentage of the sensitive order $(\mathrm{E}=$ Ephemeroptera, $\mathrm{P}=$ Plecoptera, $\mathrm{T}=$ Tricoptera) of the total taxa found. A large percentage of Taxa EPT indicates good water quality (Zimmerman 1993).

\section{Result}

The morphology of Alur Buaya depicts it as shallow but wide stream. The depth of the water are not too much different in all substations. The shallowest part occur in Station 1a and Station 1c 
where the depth are just as deep as $5 \mathrm{~cm}$. The deepest part is never more than $20 \mathrm{~cm}$ which occur in Station $3 \mathrm{a}$, and Station 3c. However, the stream wide is vary among stations ranging from $50 \mathrm{~cm}$ to 5 meters for the stream width and 4 to 12 meters for bankfull width. Complete stream morphology in all three stations with respective substations is described in Table 1.

Table 1. Alur Buaya Stream Morphology

\section{Station}

\begin{tabular}{llllllllll} 
Stream Morphology & St. 1 & \multicolumn{9}{c}{ St. 2 } & \multicolumn{2}{c}{ St. 3 } \\
& St. 1a & St. 1b & St.1c & St. 2a & St. 2b & St. 2c & St. 3a & St. 3b & St. 3c \\
\hline Stream width (m) & 0,5 & 1,3 & 3,2 & 5 & 2 & 3 & 3,5 & 3,5 & 3,5 \\
Bankful width (m) & 6 & 4 & 7,3 & 8 & 12 & 9 & 8,5 & 7 & 5 \\
Depth (m) & 0,05 & 0,09 & 0,05 & 0,1 & 0,13 & 0,13 & 0,2 & 0,15 & 0,2 \\
\hline
\end{tabular}

\section{A. Physical Properties}

Physical parameters measured from the stream includes water temperature, total dissolved solid (TDS), total suspended solid (TSS), turbidity, water clarity, and water velocity. Temperature is not too much distinct across the station. Station 1 and station 2 do not show distinctive features which ranging from $30^{\circ} \mathrm{C}$ to $31,6^{\circ} \mathrm{C}$. Station 3 is a little cooler with average temperature at $28^{\circ} \mathrm{C}$.

Water clarity reach $100 \%$ at all stations. Water velocity falls between 0,1 to $0,2 \mathrm{~m} / \mathrm{s}$ in most staions except in Station $3 c$ where the water run at $0,5 \mathrm{~m} / \mathrm{s}$.
Maximum turbidity occurs in Station 3 where the value reach 2,6 NTU in all substations and minimum turbidity is as low as 0,35 NTU across the three substations of Station 1. Whilst in all substations in Station 2, the turbidity is 1,86 NTU. Two physical parameters possessing reference value based on PP. 82 of 2001 on the Management of Water Quality and Control of Water Pollution- Class II (for agriculture, fishery and livestock) are the total dissolved solid and total suspended solid. The value of both parameters in all sampling points is described by Picture 1.

1.a. 1.b
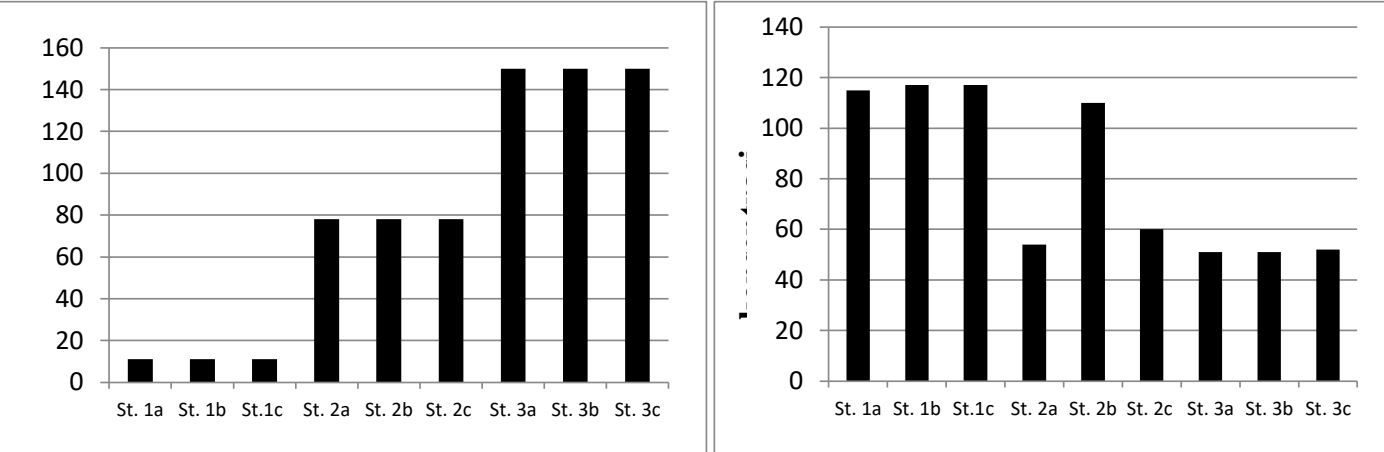

1.a Concentration of total suspended solid (TSS) in ppm in all sampling stations.

1.b. Concentration of total dissolved solid (TDS) in $\mathrm{mg} / \mathrm{l}$ in all sampling stations.

TSS concentration is similaar among substations in every sampling sites. The highest concentrations which is $150 \mathrm{mg} / \mathrm{l}$ are found in all substations of Station 3 and the lowest concentration is measured in Station 1 at $11 \mathrm{mg} / \mathrm{l}$. The same pattern is also observed in Station 1 and Station 3 for TDS where the value is almost similar across substations in each sites. Station 1 has the highest concentration with less than $120 \mathrm{ppm}$, whilst Station 3 acoounts for more than $45 \mathrm{ppm}$. However, the features in Station 2 shows that the substation $2 \mathrm{~b}$, possessing TDS which is much higher than Station 2a and statin 2c. 
The TDS value of Station $2 b$ is almost the same as Station 1 whilst the value for the other two substation are only slightly higher than station 3 .

\section{B. Chemical Properties}

Table 2. Water chemistry of Alur Buaya Stream

\begin{tabular}{|c|c|c|c|c|c|c|c|c|c|c|}
\hline & Stasiun & & & & & & & & & \\
\hline $\begin{array}{l}\text { Chemical } \\
\text { Parameter }\end{array}$ & $\begin{array}{l}\text { St. } 1 \\
\text { St. 1a } \\
\end{array}$ & St. $1 b$ & St.1c & $\begin{array}{l}\text { St. } 2 \\
\text { St. 2a }\end{array}$ & St. $2 b$ & St. 2c & $\begin{array}{l}\text { St. } 3 \\
\text { St. 3a }\end{array}$ & St. 3b & St. 3c & $\begin{array}{l}\text { Reference } \\
\text { value }\end{array}$ \\
\hline$\overline{\mathrm{pH}}$ & $4-4,9$ & $3.9-4.6$ & $3.9-4.6$ & $5.8-6.2$ & $5.6-5.9$ & $5.2-5.6$ & $5.1-5.3$ & $5.1-5.3$ & 5.4-5.6 & $6-9$ \\
\hline $\mathrm{DO}(\mathrm{mg} / \mathrm{l})$ & $6-8.2$ & $6-8.3$ & $6.2-8.8$ & $7.8-8.1$ & $4.5-7.8$ & $7.8-8.0$ & $8.1-9.7$ & $8.1-9.8$ & $8.2-9.9$ & Min 4 \\
\hline COD (mg/l) & 9.8 & 9.8 & 9.8 & 6.1 & 6.1 & 6.1 & 17.2 & 17.2 & 17.2 & 25 \\
\hline BOD (mg/l) & 3.136 & 3.136 & 3.136 & 1.952 & 1.952 & 1.952 & 5.504 & 5.504 & 5.504 & 3 \\
\hline Nitrat (mg/l) & $<0.5$ & $<0.5$ & $<0.5$ & $<0.5$ & $<0.5$ & $<0.5$ & $<0.5$ & $<0.5$ & $<0.5$ & 10 \\
\hline $\begin{array}{l}\text { Amoniak } \\
(\mathrm{mg} / \mathrm{l})\end{array}$ & Nil & Nil & Nil & Nil & Nil & Nil & Nil & Nil & Nil & Nil \\
\hline $\begin{array}{l}\text { Phosphat } \\
(\mathrm{mg} / \mathrm{l})\end{array}$ & 0.11 & 0.11 & 0.11 & 0.10 & 0.10 & 0.10 & $<0.03$ & $<0.03$ & $<0.03$ & 0.2 \\
\hline
\end{tabular}

Almost all substations of sampling sites have $\mathrm{pH}$ below 6 which ranges from 3,9 to 5,9. Only Station 2 at substation $2 \mathrm{~b}$ possesses $\mathrm{pH}$ more than 6 at its upper $\mathrm{pH}$ band. The concentration of oxygen dissolved in the water shares almost similar value in all substations of every stations with the exception of station $2 \mathrm{~b}$ which has $4,5 \mathrm{mg} / \mathrm{l}$ to $7,8 \mathrm{mg} / \mathrm{l}$. Station 1 has concentration value ranging at 6 to above 8 $\mathrm{mg} / \mathrm{l}$, whilst Station 3 have the DO concentration from 8 to almost $10 \mathrm{mg} / \mathrm{l}$.

Both biological and chemical oxygen demand have similar value among substations in all stations. The lowest COD was found in Station 2, and the highest was found at Station 3. The same pattern are also observed for BOD, Station 2 has $1,952 \mathrm{mg} / \mathrm{l}$ BOD while Station 3 reach 5,504 mg/l. Nitrate concentration are constant in all substations which is less than $0,5 \mathrm{mg} / \mathrm{l}$ and no ammonia were detected in the water samples from all station. Phosphat concentration are $0,11 \mathrm{mg} / \mathrm{l}$ at Station 1 and less than $0,03 \mathrm{mg} / \mathrm{l}$ at Station 3, whilst the lowest were occur at Station 2 with $0,1 \mathrm{mg} / \mathrm{l}$.

Based on the test results on the chemical and physical parameters, the Total Suspended Solid (TSS) and Biochemical Oxygen Demand (BOD) levels passed the Quality standard refers to PP. 82 of 2001 (Indonesian Ministry of Environment). At station $2(\mathrm{a}, \mathrm{b}, \mathrm{c})$ the TSS levels reach $78 \mathrm{mg} / \mathrm{l}$ and $150 \mathrm{mg} / \mathrm{l}$ at station $3(\mathrm{a}, \mathrm{b}, \mathrm{c})$. The BOD level of the
Water chemistry of the stream provide value $\mathrm{pH}$, biological oxygen demand (BOD), Chemical oxygen demand (COD), nitrat, amonia and phosphat. Complete value for the water chemistry is given in Table 2. alur buaya stream reached $3.136 \mathrm{mg} / \mathrm{l}$ at station 1 (a, $\mathrm{b}, \mathrm{c})$ and 5,504 mg/l at station 3 (a, b, c). TSS and Turbidity, has a low value at station 1 because the rivers have relatively little anthropogenic disturbance such as rock and sand mining, and the location is relatively far from new land clearing and plantation land rejuvenation. Unlike the case with stations 2 and 3 that many experience dredging and taking rock and sand for building materials. And relatively close to the area of land clearing and rejuvenation of oil palm plantations.

\section{Macrozoobenthos community (EPT Larvae)}

Macrozoobenthos as the bioindicator used in this research were not found in all three stations with its respective substations. The second survey also resulted in the absence of EPT larvae in all sampling points. The result was beyond expectations. However, when it was confirmed to the locals about their awareness of the larvae by showing the pictures of the specimens, they confirm that they are familiar with those pictures and the larvae were existed in the locations, but they are difficult to find recently. 


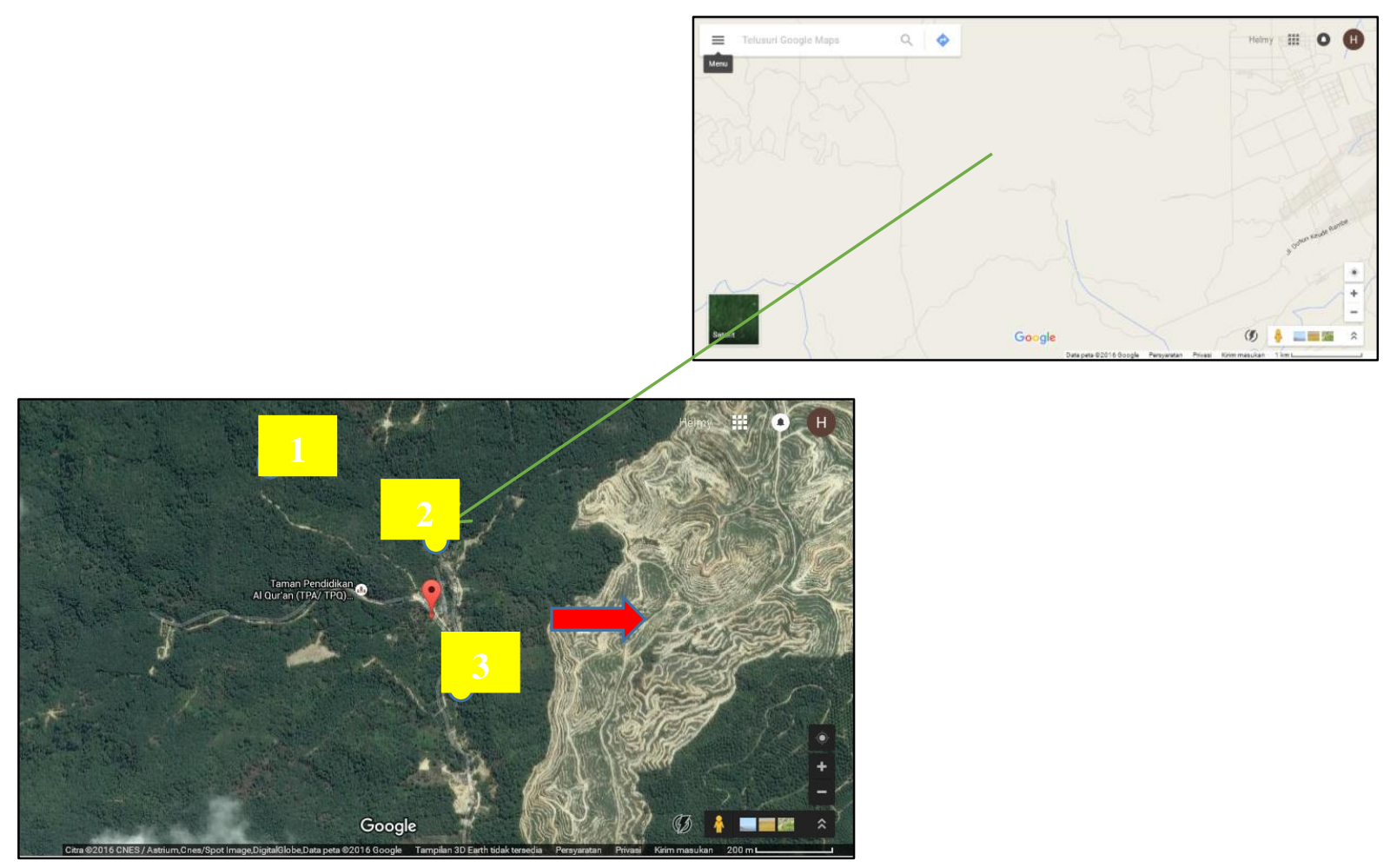

Picture 2. Location study

\section{Discussion}

Sampling results in Alur Buaya stream only results in five neuston (gerridae) in station $1 \mathrm{~b}$ and six in station $3 \mathrm{~b}$ and also one fish in Station $1 \mathrm{~b}$. The absence of macroinvertebrates including EPT larvae in a stream ecosystem is not common since they are ubiquitous and the distribution include vast geographical area all over the world. Only in an extreme environment, highly polluted and temporary water channels they are normally absent(Carter et al. 2007). The complete absence of mayflies, stoneflies and cadishflies from all stations including at the reference sites makes it difficult to examine the reason.

Some physical parameter (TSS) that exceeds the value determined in PP 82 of 2001 means that the water quality are below the government standard. The high value of TSS in Station 2 and Station 3 indicates that the sediment loading to the water body is high, especially in Sation 3, where the TSS concentration reach $150 \mathrm{~g} / \mathrm{l}$, far above the value set by he government for healthy water which is 50 $\mathrm{mg} / \mathrm{l}$. Two chemical parameters also suggested that the water is unhealthy.
The stream water can be athegorized as acidic water due to the $\mathrm{pH}$ value in eight out of nine substations were below the standard which ranges from six to nine. The National Institute of Water and Atmospheric Research (NIWA) New Zealand chategorizes $\mathrm{pH}$ value that falls below five as poor. Acid water with $\mathrm{pH}$ below five can be caused $\mathrm{y}$ the source of the water from polluted discharge or from swamp drainage. The low level of water $\mathrm{pH}$ can significantly affect the diversity of invertebrates and their individual numbers (https://www.niwa.co.nz/ourscience/freshwater/tools/shmak/manual/9habita t). Surprisingly, the acidic water in Alur Buaya stream occurs in all sites including the reference site which was assumed to be intact but possesing the lowest $\mathrm{pH}$ which is 3,9 .

Moreover, biological oxygen demand (BOD) in Station 1 ad Station 3 were also above the government standard. The source of BOD in a stream are normally from organic material loadings (Tyagi et al. 1999) which can originated from domestic and industrial sewage, farms, and industrial water discharge. The highest BOD of Alur Buaya stream occur at Station 3, whose 
concentration exceeds $5,5 \mathrm{mg} / \mathrm{l}$. The high level of BOD at Staton 3 might be originated from the organic loading from the farm, whilst the high concentration at the reference site remain questioned.

The three parameters could be indicatioond that Alur Buaya stream is polluted. But cannot justify the absence of EPT larvae in the area since zero number of EPT presence eliminate the opportunity to test the association between species diversity, and abudance agaist the environmental gradients. A study by Tyagi et al. 1999, suggested that altitude, hydrologic classification (order) and vegetation cover were the most important factors affecting the distribution of EPT larvae.

Although the Alur Buaya is a low-order streams that should have healthy ecosystem conditions, it will be lower due to high levels of anthropogenic disturbance causing chemical and physical parameters such as TSS and BOD exceeds quality standards. It is also the cause of biodiversity loss from the EPT group which is an indicator of the quality of the streams.

The high scores of diversity indices, such as those of the Shannon-Wiener index and Simpson's index, indicate that clean or unpolluted rivers support more diverse taxa, thus making them useful for detecting organic pollution (Lenat \& Penrose 1996). At the location of the study were not found taxa of EPT, this shows the high disturbance to the ecosystem of alur buaya in generally.

High concentrations of suspended solids can lower water quality by absorbing light. Waters then become warmer and lessen the ability of the water to hold oxygen necessary for aquatic life. Because aquatic plants also receive less light, photosynthesis decreases and less oxygen is produced. The combination of warmer water, less light and less oxygen makes it impossible for some forms of life to exist.

The three orders of the above insects are the most widely used orders because they have a very wide geographical range, and their nature is very sensitive to changes in physical and chemical quality of the waters. EPT biomonitoring is based on diversity, abundance, and distribution that will change according to changes in water quality (Wahizatul, Long, and Ahmad 2011).

Suspended solids affect life in other ways. They can clog fish gills, reduce growth rates, decrease resistance to disease, and prevent egg and larval development. Particles that settle out can smother fish eggs and those of aquatic insects, as well as suffocate newly-hatched larvae. The material that settles also fills the spaces between rocks and makes these microhabitats unsuitable for various aquatic insects, such as mayfly nymphs, stonefly nymphs and caddisfly larva. Based on information from people who are mining rock and sand in the river. Larva EPT order is already difficult to find. but sometimes the miners still find especially when the dry season and there is a little water inundated. but it is very rare.

Addtional informaton from locals who claimed to be familiar with the water insects indicated that the three orders of insects were existed in the stream, but no longer be seen recently, however, this claim must be tested in a more formal research.

\section{Conclusions and Recommedations}

Alur Buaya can be cathegorized a polluted stream based on the physical and chemical properties of the water. Sampling for EPT larvae as bioindicators resulted in no specimen was trapped in sampling devices, which eliminated the chance to test the factors affecting the Ephemeroptera, Plecoptera and Trichoptera distributions in Alur Buaya stream, and thus prevent the opportunity of using these insects as bioindicator of a stream quality in the area.

Further investigation should be done to assess the presence of the insects in Kota Langsa freshwater ecosystm by taking other intact streams as sampling sites to examine whether the absence only occur in Alur Buaya stream or they are also cannot be found at other riverine system which indicate that these order are absence within this geographical area.

\section{Acknowledgement}

The authors would like to thank the DRPM Kemenristekdikti (Ministry of research, technology and higher education) who has funded this research through a lecturer's research grant for beginner 2017. Mr. Akmal Haki and Mr. Muhammad Fauzan Isma who helped during the research. 


\section{Refferences}

Burger, Joanna, Michael Gochfeld, Charles W. Powers, James H. Clarke, Kevin Brown, David Kosson, Lawrence Niles, Amanda Dey, Christian Jeitner, and Taryn Pittfield. 2013. "Determining Environmental Impacts for Sensitive Species: Using Iconic Species as Bioindicators for Management and Policy." Journal of Environmental Protection 04 (August): 87-95. doi:10.4236/jep.2013.48A2011.

Carter JL, Resh VH, Hannaford MJ, Myers MJ (2007) Macroinvertebrates As Biotic Indicators Of Environmental Quality. In: Hauer FR, Lamberti GA (eds) Methods in Stream Ecology, 2nd edn. Academic Press, China, pp 805-834

Comte, Irina. 2012. Agricultural Practices in Oil Palm Plantations and Their Impact on Hydrological Changes, Nutrient Fluxes and Water Quality in Indonesia: A Review. Advances in Agronomy. 1st ed. Vol. 116. Elsevier Inc. doi:10.1016/B978-0-12394277-7.00003-8.

Comte, Irina, François Colin, Olivier Grünberger, Joann K Whalen, Rudi Harto Widodo, and Jean-pierre Caliman. 2015. "WatershedScale Assessment of Oil Palm Cultivation Impact on Water Quality and Nutrient Fluxes: A Case Study in Sumatra ( Indonesia )." Environmental Science Pollution Research. doi:10.1007/s11356015-4359-0.

Davis, Stephanie, Stephen W Golladay, George Vellidis, and Catherine M Pringle. 2003. "Impacted by Animal Agriculture." Journal of Environmental Quality 32: 1036-43.

Dodds, Walter K. 2006. "Nutrients and the 'Dead Zone ': The Link between Nutrient Ratios and Dissolved Oxygen in the Northern Gulf of Mexico In a Nutshell:" Frontiers in Ecology and Environment 4 (4): 211-17.

Hamid, Abdul, Suhaila Rawi, Che Salmah, and Salman Abdo Al-shami. 2012. "Temporal Distribution of Ephemeroptera , Plecoptera and Trichoptera (EPT) Adults at a Tropical Forest Stream: Response to Seasonal Variations" 32: 28-34. doi:10.1007/s10669011-9362-5.
Hepp, Luiz Ubiratan, and Sandro Santos. 2008. "Benthic Communities of Streams Related to Different Land Uses in a Hydrographic Basin in Southern Brazil Benthic Communities of Streams Related to Different Land Uses in a Hydrographic Basin in Southern Brazil." Environmental Monitoring Assessment 157 (April 2016): 305-18. doi:10.1007/s10661-008-0536-7.

https://www.niwa.co.nz/ourscience/freshwater/tools/shmak/manual/ 9habitat. Accessed on 12 October 2017.

Ichwana , Zulkifli Nasution, and Sumono. 2013. Determining Groundwater Recharge from Stream Flow with Seasonal Recession Method. Aceh International Journal of Science and Technology, 2 (1): 8-16. April 2013. ISSN: 2088-9860

Irfan, M, and M Utiyal Huda. 2012. "Pengaruh Alih Fungsi Lahan Hutan Menjadi Perkebunan Kelapa Sawit Terhadapsifat Kimia Tanah (." Jurnal Agroteknologi 3 (1): 29-34.

Irham, M., Y Fadhla, and I Setiawan. 2018. The spatial distribution of suspended sediment analysis along Krueng Cut River, Banda Aceh. The 4th International Seminar on Sustainable Urban Development IOP Publishing IOP Conf. Series: Earth and Environmental Science 106 (2018) 012066. doi :10.1088/1755-1315/106/1/012066

Juahir, Hafizan, Sharifuddin M. Zain, Mohd Kamil Yusoff, T. I Tengku Hanidza, A. S Mohd Armi, Mohd Ekhwan Toriman, and Mazlin Mokhtar. 2011. "Spatial Water Quality Assessment of Langat River Basin (Malaysia) Using Environmetric Techniques." Environmental Monitoring and Assessment 173: 625-41. doi:10.1007/s10661-010-1411-x.

Lenat D R and Penrose D L. (1996). History of the EPT taxa richness metric. Bulletin North American Benthological Society 12(13): 279-290.

Magurran, Anne E. 2004. "Chapter 2-4." In Measuring Biological Diversity, 18-130. Carlton, Victoria: Blackwell Publishing.

Mulyani Mulyani, Marwan Marwan and Nazli Ismail. 2012. River Water Quality Spatial Analysis Based on Physical Parameter 
Throughout Krueng Daroy in Banda Aceh. Journal of Aceh Physics Society, SS, Vol. 1, No. 1 pp. 1-2, 2012.

Susila, Wayan R. 2004. "Contribution of Oil Palm Industry to the Economic Growth and Poverty Alleviation in Indonesia." Jurnal Litbang Pertanian 23 (3): 107-14.

Tyagi B, Gakkhar S, Bhargava DS (1999) Mathematical modelling of stream DOBOD accounting for settleable BOD and periodically varying BOD source. Environ Model Softw 14:461-471. doi: 10.1016/S1364-8152(98)00091-7

Wahizatul, A. A., S. H. Long, and A. Ahmad. 2011. "composition and distribution of aquatic insect communities in relation to water quality in two freshwater streams." Journal of Sustainability Science and Management 6 (1): 148-55.

Whitehead, P. G., R. L. Wilby, R. W. Battarbee, M. Kernan, and A. J. Wade. 2009. "A Review of the Potential Impacts of Climate Change on Surface Water Quality." Hydrological Sciences 54 (1): $101-23$. doi:10.1623/hysj.54.1.101.

Wu, J.T. 1984. "Phytoplankton As Bioindicator For Water Quality In Taipei.” Botanical Bulletin of Academia Sinica 25: 205-12.

Yaap, Betsy, Matthew J. M.J. Struebig, Gary Paoli, L.P. Lian Pin Koh, and Lian Pin Koh. 2010. "Mitigating the Biodiversity Impacts of Oil Palm Development." CAB Reviews: Perspectives in Agriculture, Veterinary Science, Nutrition and Natural Resources 5 (019): 1-11. doi:10.1079/PAVSNNR20105019.

Yusop, Z, C H Chan, and A Katimon. 2007. "Runoff Characteristics and Application of HECHMS for Modelling Stormflow Hydrograph in an Oil Palm Catchment," 41-48. doi:10.2166/wst.2007.690.

Zimmerman, Melvin C. 1993. "The Use of the Biotic Index as an Indication of Water Quality." In Proceedings of the 5th Workshop/Conference of the Association for Biology Laboratory Education (ABLE), 85-98.

Zuloaga, O., A. Prieto, A. Usobiaga, S. K. Sarkar, M. Chatterjee, B. D. Bhattacharya, A. Bhattacharya, Md A. Alam, and K. K.
Satpathy. 2009. "Polycyclic Aromatic Hydrocarbons in Intertidal Marine Bivalves of Sunderban Mangrove Wetland, India: An Approach to Bioindicator Species." Water, Air, and Soil Pollution 201 (1-4): 305-18. doi:10.1007/s11270-008-9946-y. 